\title{
INFORMATION TECHNOLOGIES IN THE AGRICULTURAL SECTOR OF UKRAINE
}

\author{
Liudmyla Kysh \\ Candidate of Economic Sciences, Associate Professor at the Department of Computer \\ Sciences and Economic Cybernetics, Vinnytsia National Agrarian University, Ukraine \\ e-mail: lyudmilaakish@gmail.com,orcid.org/0000-0002-3664-3871
}

\section{Summary}

Rural development is largely determined by the use of more advanced forms of management, which ensure the effective use of the economic mechanism in specific production conditions. The system of agricultural research and education in the field of agricultural economics does not yet contribute to the maximum development of the agro-industrial complex. It absorbs a larger share of budget expenditures on agricultural GDP and as a percentage of total GDP than in other countries in comparable countries. The author identifies a number of unresolved issues of legal, organizational, technical, scientific and methodological, analytical, resource support for the development of the information society. The aim of the article is to study the current working conditions of information and communication support in Ukraine, to emphasize the main results of information and consulting services in Poltava region, their international cooperation and contribution to the spread of new information technologies in the agricultural sector. It is determined that improving the quality of information and communication software can play a crucial role in improving the efficiency of agricultural enterprises in Ukraine. The implementation of information and communication technologies and their widespread use in various spheres of human life, society and the state is one of the most important tools that contributes to raising the level of economic, social, cultural and technological development.

Keywords: information technologies, agricultural enterprises, efficiency, information and consulting services, agricultural sector.

DOI: https://doi.org/10.23856/4916

\section{Introduction}

In market conditions, the development of communication technologies is extremely important for the Ukrainian agricultural sector, as the possession of information and its application in production process is directly related to ensuring food security of the state. Rural development is largely determined by the application of more advanced forms of management ensuring the effective use of the economic mechanism in specific production conditions. That's why you need to consider a variety of information processing and analysis tools. Nowadays information, transmission, software and hardware are not less important resources than material and energy. The transfer of information in the agricultural enterprises management system requires effective organization (Larin et. al, 2013). Therefore, improving the quality of information and communication software can play a crucial role in improving the efficiency of Ukrainian agricultural enterprises. It will allow to focus on legislation, projected rates of production and sales, geography of prices for products and resources to determine the strategy of economic development, introduction and use of new technologies, production, storage and sales and build financial relations tactically properly (Larin et. al, 2013). Nowadays, the development 
of an effective system of information and communication security is one of the most important factors of the agricultural sector effective development. Theoretical and methodological foundations of informatization of agricultural production, the formation of information security and its role in the agricultural sector management, the establishment of consulting services have been researched by Ukrainian scientists (Larin et. al, 2013; Khudyakov, 2016; Chekhlatyi, 2008; Kalinichenko et. al., 2009; Pustovit, 2008; Tzuferova, 2012). However, systematic research on information and communication support of the agricultural sector and the information needs of the business entity has not been researched yet. The importance of the above issues, the need for their thorough theoretical research and practical specification have caused the relevance of our subject of research, its goals and objectives.

The main purpose of the article is to research the current working conditions of information and communication support in the agricultural sector of Ukraine.

\section{Review of innovative tools for the development of agricultural enterprises}

Modern development of any country is impossible without the introduction and application of various innovations. It provides a level of competitiveness in both domestic and foreign markets. Integrated implementation of innovations helps to increase labor productivity, saves various resources, reduces costs, reduces the cost of agricultural products, increases the efficiency of agricultural production, and affects investment (Larin et al., 2013). The development and implementation of information technology in the agricultural sector is widely developed with the help of advanced technologies, the security of some of them has not been fully researched. Therefore, these processes are accompanied by various risks, such as negative impact on public health through consumer goods, on natural resources, i.e., groundwater due to the intensification of agricultural activities and uncontrolled application of untested innovative technologies in the production process (Khudyakov, 2016). It affects the public demand decline because of these innovative technologies. Every year the technology develops faster and faster, so the introduction of modern innovative technologies is a very important issue. In modern conditions, the economy of the agricultural sector is developing very slowly due to the economic crisis, expensive training of staff, insufficient incentive for government involvement of the IT technology introduction in the agricultural sector, and low territory attractiveness to invest in this issue. Many different agricultural companies are involved in the introduction of the latest information technologies in the agricultural sector. Such companies as CLAAS and John Deere have made a very important contribution to the development of IT technology for agricultural machinery. John Deere introduces innovative technologies such as the StarFire receiver; GreenStar 1800 display; LightBar, Parallel Tracking, iGrade, i-Farming, AutoTrac Row Sense, AutoTrac etc. However, these technologies are very expensive. Agro IT has also made a significant contribution to the development of technologies such as COPILOT (Tzuferova, 2012).

Agricultural helicopters are also widespread in the agricultural sector. Many fields have different terrain, but it is almost impossible to look at the terrain of large fields, so these drones are used for this purpose. Agricopters are able to fly over the field at altitude, just fly over the field taking a photo or video, which is very useful for large agricultural holdings. The drones allow farmers to monitor the condition of the soil, the quality of ploughing and sowing, crop forecasts, protect the area from fire and theft, and indicate the soil improvement by applying fertilizers. About half of the pesticides and herbicides used in crop production are useless if consumed in larger quantities than needed or not used where needed. The technology has reached the point 
where small drones weighing only a few kilograms are able to fly over large areas of fields at a speed of $80 \mathrm{~km}$ per $\mathrm{h}$, researching it and transmitting information to specialists who need it for further action. The experience of drone application has shown the advantage of helicopter-type drone application compared to planes in the agricultural sector. Agricopters can also fly for a long time with the video surveillance system turned on, to monitor real economic activity, and use the services of agricultural consultations or online security services.

Today, the market for civil unmanned engineering focused on agriculture is considered the most promising. According to EU regulations, from 2015 to 2020 consumer demand for drones included $25 \%$ of fire drones, $13 \%$ of drones for agriculture and forestry, $10 \%$ of energy, $6 \%$ of control over the earth surface, and $1 \%$ for broadcasting. However, American researchers from the organization AUVSI studied the drone market, they came to conclusion that it is expected that in the world the main consumers of unmanned civilian production will be farmers by the middle of the $21^{\text {st }}$ century (Larin et. al, 2013).

Some companies provide services for the drone application, they provide certain recommendations and analytical information. It is very effective because the cost of modern agricultural helicopters is very high. In addition, analytical information is provided by professional staff, which is also important in the agricultural sector. These companies also give a guarantee for their services.

\section{Problems of information and communication technology introduction}

The introduction of information and communication technologies (ICT) and their widespread application in various spheres of human life is one of the most important tools improving the level of economic, social, cultural, and technological development (Larin et. al, 2013; Khudyakov, 2016; Chekhlatyi, 2008; Kalinichenko et. al, 2009). Over the past ten years, Ukraine has begun to develop the information society; it was confirmed in a number of conceptual and strategic documents, primarily in the Law of Ukraine on the Fundamentals of the Information Society in Ukraine for 2007-2015.

At the same time, there are lots of unsolved issues of legal, organizational, technical, scientific, methodical, analytical, resource support for the information society development. A large number of government decisions on these issues are unsystematic, they are borrowed from other countries without taking into account the current state and trends in Ukraine. The annual report on the state of information and communication support in Ukraine confirms this point of view, it is developed and submitted to parliament by the government together with the draft state budget for next year in accordance with the National Informatization Program.

It should be emphasized that this document has some drawbacks in both the formation and implementation, namely:

- lack of documents analysis and real impact on the budget process;

- incomplete and inaccurate data of the State Statistics Committee and other public authorities, including:

- delay in the document consideration in parliament; formation.

- ignoring the procedures of strategic monitoring, analysis and forecasting of its

It performs a very important function despite the above-mentioned drawbacks because it informs citizens, society and the state about the situation in this area, the main factors and trends, and short-term priorities of public policy (Khudyakov, 2016; Chekhlatyi, 2008; Kalinichenko et.al., 2009; Pustovit, 2008; Tzuferova, 2012). 
Because of the economic crisis and the war in Ukraine over the past year, the rate of enterprises computerization in various sectors of the economy has decreased; funding for information projects from the state budget has almost halved, and the National Informatization Program has decreased tenfold (Kalinichenko et. al., 2009; Pustovit, 2008; Tzuferova, 2012).

Therefore, according to the World Economic Forum ICT indices the ratings of Ukraine are as follows:

- according to the WEF Global Competitiveness Index Ukraine is $79^{\text {th }}$ out of 140 countries (it was $76^{\text {th }}$ out of 144 countries in 2014);

- according to the WEF Network Readiness Index Ukraine is $71^{\text {st }}$ out of 143 countries in 2015 (it was $81^{\text {st }}$ out of 148 countries in 2014)

- according to the WEF Technology Readiness Index Ukraine is 86th out of 140 countries in 2015 (it was $94^{\text {th }}$ out of 148 countries in 2014).

According to the UN Global e-Government Development Index, in 2014 Ukraine was 87 in the world out of 193 UN member states (in 2012, Ukraine was $68^{\text {th }}$ out of 190 countries). Despite the loss of positions in the rankings, in particular, in the index of online services, Ukraine joined the group of countries with a high e-government index in 2014, which is considered a positive tendency for the country (Chekhlatyi, 2008).

According to the International Telecommunication Union Report on Measuring the Information Society 2015, which includes ratings of 167 countries, Ukraine was $79^{\text {th }}$ according to the ICT Development Index (according to the ITU Report for 2014, Ukraine was $73^{\text {rd }}$ out of 166 countries).

Uneven access to ICT in the regions is one of the reasons for the Ukrainian low level in this ranking, it is confirmed by the results of the analysis of the development of information and communication infrastructure and ICT in different regions. According to the World Wide Web, Ukraine ranked $46^{\text {th }}$ out of 86 countries in the web index for the ranking of Internet development in 2014.

According to the Broadband Status 2015 annual report prepared by a joint initiative of the International Telecommunication Union and UNESCO, the level of Internet penetration in Ukraine ranked $95^{\text {th }}$ out of 191 countries (in 2013 it was $94^{\text {th }}$ out of 191 countries) (Kalinichenko et.al, 2009).

Unfortunately, today there is no strategy or effective mechanisms for the development of the information society in Ukraine. There is no strategy for forming these mechanisms considering global trends in ICT development, Ukrainian features of information society, modern approaches and management methods (Pustovit, 2008; Tzyferova, 2012). The process of informatization of the agricultural sector is worse than of other sectors in Ukraine. It is due to its peculiarities. However, agriculture is an ideal environment for the modern information technologies application. However, the lack of funds in the field of agricultural science and production does not guarantee their widespread use (Pustovit, 2008; Tzyferova, 2012).

The role of the state in the agricultural sector has not been defined yet. A separate national program on informatization and automation of agriculture is needed. That's why, the steps, goals and results must be clearly defined. It is important to consider this issue comprehensively, and it is necessary to develop a system that would take into account a wide range of information agribusiness development (Kalinichenko et. al., 2009; Khudyakov, 2016).

Having analysed the ICT introduction in agriculture, we can conclude that compared there is a significant gap in terms of their application comparing to other sectors of the economy. It can be explained by such main points as lack of tools in most modern computer technologies, lack of qualified specialists in the field of information technology, lack of relevant information and software to automate the management of agricultural enterprises (Kalinichenko et. al, 2009; Khudyakov, 2016). 
The latter reason is the most important among all the above-mentioned reasons because the purchase of computer equipment and training of relevant specialists does not cause any problems. However, there are some difficulties in the development and creation of software and information management due to the lack of appropriate methods that would allow the use of computers and related software in the process of agricultural management tasks (Kalinichenko et. al., 2009; Khudyakov, 2016).

Ukraine is constantly working to improve the current situation despite a large number of problems with the introduction and provision of the agricultural sector with the latest information and communication technologies. First of all, the training of qualified personnel for information and analytical support of the Ukrainian economy is provided. Contributions to the spread of new information technologies and information and communication software systems are made by educational institutions training specialists for the agricultural sector. It is worth paying attention to the National University of Life and Environmental Sciences of Ukraine (NULES), the largest agricultural university in Ukraine, where more than 26 thousand students study. The university includes the Department of Information Technology, and the Ukrainian Educational and Research Institute (ERI) of information and telecommunications support of the agricultural and environmental sectors of the economy (Pustovit, 2008).

Specialists from the world's leading manufacturers of hardware and software are involved for the practical training of students. In particular, IBM Corporation in Ukraine conducts training seminars and training courses at the Faculty of Computer Science and Economic Cybernetics. Software from Apple, Micro Strategy, Sun, IBM, SearchInform, etc. began to be introduced into the educational process.

The Research Institute for Information Technology in Environmental Management has combined activities of research and innovation laboratories. The information and analytical system for monitoring the socio-economic development of the agro-industrial complex of Ukraine is one of the useful innovations that have been implemented. This software for monitoring agricultural market objects is based on technology that allows for structural analysis of the location and infrastructure of agriculture, as well as a list of their characteristics.

The results were presented using the most informative map service. This model was awarded a gold medal of the international exhibition Agro-2012; it allowed to develop an effective model of the system of storage, display and analysis of socio-economic information about the state of the agricultural and environmental sectors based on the use of the software platform for business intelligence entitled Microstrategy.

A software system of information and analytical support of producers on the harvest of spatial data was developed (diploma Agro-2012); the geoportal of NULES of Ukraine with a set of geological information services was created. The research was conducted in several areas within the framework of the state program of information technology development for the agricultural sector of Ukraine.

The creation of the Internet portal Agrarian Sector of Ukraine (AgroUA.net) was the institute's contribution to improving access to agricultural information. Its purpose was to develop a universal and comprehensive information resource to meet the needs of agricultural information, agricultural producers, commercial organizations, advisory services, researchers, teachers, students and other users (Chekhlatyi, 2008). Nowadays, the staff of the Institute has been successfully creating an electronic counseling system eXtension on the basis of NULES of Ukraine.

It is well known that the lack of information in the modern Ukrainian countryside is the cause of many problems. Agricultural practice in most developed countries indicates the need for continuous training of producers, dissemination of agricultural information and knowledge. 
Therefore, it is necessary to provide powerful channels for the dissemination of knowledge. There are now qualitatively new forms of dissemination of operational information based on the benefits of modern computer networks and telecommunications. Particular attention should be paid to the US experience in developing an eXtension (electronic system for agricultural expansion).

The researched experience can be used for creation of electronic system of expansion (e-Extension) in Ukraine. It should be mentioned that the system of providing information and advice has been a difficult task for the dissemination of information and knowledge among agricultural producers in Ukraine for a long time. The aim of this project was to create an electronic system of consultations on education (e-Extension) for information support of farmers, rural residents and rural development of the electronic system of expansion (e-Extension) in Ukraine. The purpose of the electronic extension system is to provide objective, scientific, technical and educational information to the public to answer users' questions. This is achieved by creating a national online database of high-quality information based on innovations and the concept of sustainable development of the system of electronic expansion of agriculture (e-Extension) in Ukraine.

The developers of the system foresaw and defined the main ideas of the project:

- electronic extension should meet the needs of users who want to receive the necessary information anywhere and anytime, provide them with quick access to the resources of organized personalized access needed to make informed decisions;

- e-extension is applied to modern Internet technologies to help consultants at the national level, providing the necessary information support to users of agricultural products and promoting the creation and development of a community of practitioners, organizing discussion groups, establishing local contacts and interacting with consultants from all existing services;

- information databases and e-extension services should be available via the Internet to a wider audience of web users, who can access various educational resources at any time;

- users of e-Extension will be able to find objective, sound information collected by universities, research centers and experts throughout the electronic system of e-Extension in Ukraine.

Newsletters, innovations, online responses, thematic discussion groups and training modules created by consultants and related industries will help users quickly find the information they need.

The above-mentioned issues will provide an opportunity to improve information and consulting support of the agricultural sector of our country and communication capabilities of advisory services in the future. However, the advisory service has made a significant contribution to the development and creation of an information system for the agricultural sector of Ukraine.

In Ukraine, the process of creating advisory services became the most common after the adoption of the Law of Ukraine on Advisory Activities in Agriculture of June 17, 2004. According to the latest register of the Ministry of Agrarian Policy of Ukraine, 71 agricultural advisory services were established in Ukraine in early 2016 (there were only 26 advisory services in 2008). The first advisory service in Poltava called the Poltava Regional Agricultural Advisory Service (PRAAS) was established in 2004. This project was the result of an intergovernmental agreement of 15 June 2004 signed by the Federal Ministry of Food, Agriculture and Consumer Protection, and the Ministry of Agrarian Policy of Ukraine (Tzyferova, 2012).

The Internet resources have also been used to advise agricultural workers and leading industry professionals to improve their efficiency. The Porada website has been developed, it is a universal resource for meeting the information needs of agricultural areas. The site has a large number of structured sections that present a large number of materials on the most pressing issues for farmers. The most important are Accounting, Current Issues, Landscaping, Livestock, Crops, News, and Tips sections. The advisory services page has links to sites that are most popular with farmers, and a forum for public discussion of important issues and problems. 
You can also write personal messages, send a request to the administrator or ask questions related to the scope of the service moderator. You can find many practical tasks related to agricultural consultations, production issues faced by the consultant in his daily work, news and messages related to agricultural producers. The experience and recommendations of leading experts in the field of agriculture, Poltava State Agricultural Academy (STAA) and the Department of Agricultural Development of Poltava Regional State Administration were collected here (Tzyferova, 2012).

The Poltava Regional Agricultural Advisory Service employees have also their own personal Internet blogs created on the free Google service Blogger.com (BlogSpot), they can share information on issues most interesting for the agriculture. Due to the growing demand for qualified advisory services, the need to address the lack of effective mechanisms for cooperation in the field of agricultural science, education and agriculture arose before the establishment of advisory services that would be an alternative to existing ones in Poltava region. It could provide effective socially oriented advisory services to farmers and rural areas using the existing technical, scientific and organizational capacity of the PSAA. This service was established in 2007, it was given the right to provide socially oriented counseling services at the expense of the state budget. This body was named Poltava Regional Public Organization Official Agricultural Advisory Service (Kalinichenko et. al., 2009). An Internet resource was created in order to disseminate information about the activities of the new advisory service; it was a site. However, the financial crisis in Ukraine in 2008 had a negative impact on the financing of service activities and design, as well as on the support of its website. The work of the service was not organized on a commercial basis, it was aimed at providing socially oriented advisory services from the state budget, a sharp reduction in public funding almost tenfold in 2009 compared to the previous year, raised its activities in an extremely difficult situation. However, the Official Agricultural Extension Service has not slowed down, despite the difficult financial situation financed by the state. His work has largely shifted to collaboration with international organizations and projects. Official Agricultural Extension Service has gained significant experience in international cooperation and participation in various projects, which allows not only to adopt best practices, but also the necessary funds for various educational activities. The creation of a textbook on distance learning was one of the projects results. The modern information technologies application allows distance learning without direct personal contact between teacher and student, it was founded on the basis of distance education.

Electronic textbooks are an important and necessary component of distance education. PSAA scientists have developed an electronic manual on advisory services in order to train specialists in advisory services and students of higher education institutions, this electronic manual corresponds to a special curriculum and was commissioned by the Ministry of Agrarian Policy and Food of Ukraine; it included 5 modules, i.e., theoretical, legal, economic, environmental training and ICT. The manual contains the necessary background information, and the modules are accompanied by tests for self-monitoring (Kalinichenko et.al, 2009). This textbook is the first electronic textbook in Ukraine classified by the Ministry of Agrarian Policy and Food of Ukraine. modern Such programming languages as HTML, XML, JavaScript were used for the electronic manual developing. The program wrapper was used to ensure the compactness of the software.

The electronic textbooks and manuals have a number of advantages, i.e., storage automation, virtually unlimited amount of information, and relatively low production costs. It should be noted that the structure, ease of use and clarity of the material in the manual are provided by hypertext. The user has the ability both to view pages and control the issuance and reception of material (Kalinichenko et. al., 2009). PSAA and Official Agricultural Extension 
Service successfully completed another joint environmental project "TempusTacis 2006" (JER_27168_2006), its was to establish the Agroecological Centre of Poltava Region; it had to address such important environmental challenges as:

- improvement of environmental education;

- gaining experience by Ukrainian experts in the field of environmental issues;

- studying the possibility of implementing international environmental standards in Ukraine;

- dissemination of environmental information and research results (Pustovit, 2008).

The site International Agri-Environmental Centre was developed in order to disseminate information about the work of the Centre. The information posted on the Centre's website is very valuable for farmers. The idea of a digital library centre is interesting in terms of effective distance learning of agricultural producers. The site contains electronic publications of the series Ecological Library of Poltava region, booklets on the state of the environment in Poltava region containing analytical information on air quality, water resources, drinking water quality, land resources, waste and recreational resources.

It is obvious that the main task of advisory services in the agricultural sector of Ukraine is to disseminate information among agricultural producers. Their effective functioning is possible primarily through the modern information and communication technologies application by agricultural producers. The use of information technology in advisory services significantly reduces management costs, expands the access of farmers and the rural population to sources of information and communication, and facilitates a profitable economy.

\section{Conclusions}

Today, Ukraine ranks last in Europe by all indicators of information (coverage density and bandwidth of telecommunications and computer networks, Internet users, the share of broadband Internet in total, etc.). In terms of Internet access, Ukraine lags far behind developed countries.

Information technology occupies a very important and prominent place in the agricultural sector. Many companies develop innovative technologies, equipment for agricultural machinery and production. They offer agrocopters (drones) in both domestic and foreign markets. Many farmers and owners of agricultural holdings are satisfied with the work of these innovations. Unfortunately, it has its weaknesses.

First, it is the cost of these innovations. Large agricultural holdings buy various innovative technologies because they have a large cash flow, and therefore the price is not a problem for them. But many farmers cannot afford to spend a lot of money to buy, for example, agricultural helicopters. Therefore, the high cost of innovation is an urgent problem today.

Secondly, many investors do not want to invest in the development of information technology because they do not know whether this area will develop and whether they will be able to earn in this area. With the development of information technology, the agricultural sector will succeed, especially in Ukraine as an agricultural country.

Third, new information technologies require specific knowledge to use them without problems. Manufacturers can develop some courses or workshops to learn how to work with their information technology. However, these are additional expenses. That's why employees working with these innovations must take special training courses. Unfortunately, our agricultural sector is almost completely static, not developing. Innovation producers aim to make money selling their innovations, they also to teach people to work with them. They can allocate some money and create courses for people who need knowledge about the proper use of their information technology. This contrast also encourages farmers and workers to buy and use these innovations in their work, which is a good marketing solution. Purchase some equipment or technology and give free lectures on how to use this equipment. 
The experience of developed countries shows that the use of the latest information technologies and information support systems is a necessary condition for high-tech agricultural production and management. It is well known that Ukraine is one of the world's largest potential producers of agricultural products. Improving information and communication for the agricultural sector provides a significant opportunity to increase agricultural production and become one of the largest food producers. Of course, fulfilling these tasks should help producers and the state. Its assistance should become one of the main priorities of the state agricultural and information policy. Considering fact that advisory services make a significant contribution to the awareness of agricultural producers, expand their competitiveness, solve the problem of employment of the rural population, there is a need to support them at the state level.

The practical lack of public funding is the most serious challenge to the existence of agricultural advisory services in Ukraine. Currently, the only way to solve this problem is to attract local budget funds, international grants and financial assistance of foreign investors. The situation can change for the better only if the financial crisis is overcome and the economic situation in the country improves. If the financial security of consulting services in Ukraine improves it will be possible to state the prospects of providing them with innovative technologies. It will increase the efficiency of agricultural advisory services, the quality of information and advisory support, and promote the organization of competitive production.

\section{References}

1. Chekhlatyi, O.M. (2008). The Development and the Establishment of Agricultural Advisory Services in Poltava Region. Scientific Bulletin of S. Z. Gzhytsky National University of Veterinary Medicine and Biotechnology in Lviv. P. 489-493.

2. Draft concept of the Design of an Advisory Services Electronic System (e-Extension) in NULES of Ukraine. Retrieved from: http://edorada.org/

3. Kalinichenko, A. Chekhlatyi, O. (2009). Development and International Cooperation of the Informational Services and Consultation to Ensure the AIC in Poltava Region. Bulletin of KhAI. Series "Economics of Agriculture and Natural Resources”. P. 60-68.

4. Kalinichenko, A. Chekhlatyi, O. Gorb, O. (2011). The Formation and the Development of the Advisory Services System at Poltava State Agrarian Academy. Collection of scientific and methodical works "Science and technique". P. 52-58.

5. Kalinichenko, A. Chekhlatyi, O. Kostohlod, K. (2009). Features of Information Support of Agricultural Enterprises in Poltava Region. Proceedings of TSAU. P. 354-361.

6. Khudyakov, H.O. (2016). The Role of Information Security in the Management of Agricultural Enterprises. International Internet-conference "Formation and Development of the Economy under Current Economic Conditions”. Retrieved from: http://www.wp.viem.edu.ua/

7. Larin, N.B. Rudenko, O.M. (2013). Information and Communication Provision of Efficient Funstioning of Power. Educational and methodological materials. P. 5-7.

8. Pustovit, S.V. (2008). International Project to Found an Agro-Ecological Centre in Poltava. Materilas of the International scientific and practical conference "Methods of teaching natural sciences at high school”. P. 363-365.

9. Tzyferova, N.H. (2012). Information management mechanism of state regulation of a agriculture complex. Scientific Notes National University “Ostroh Academy”. Series: Culture and social communication. P. 72-78.

10. Ukrainian ESI Information and Telecommunication Support of the Agricultural and the Environmental Sectors of Economy. Retrieved from: http://nubip.edu.ua/ node/9488 